\title{
Research Article: Awareness and adoption of organic farming by the vegetable growers
}

\author{
N.B. LOTHE, V.V. GOHAD, R.A. SHELKE AND S.B. PATIL
}

Article Chronicle: Received :

21.06.2017;

Revised :

05.09.2017;

Accepted :

22.09.2017

\section{KeY WoRds:}

Awareness, Adoption, Organic farming, Vegetable growers, Constraints
SUMMARY : The present study on awareness and adoption of organic farming by the vegetable growers was conducted in the year 2016-2017 in Amravati district. The relationship of the selected variable i.e. training received, possession of livestock, extension contact and innovativeness was found to be positively and highly significantly at 0.01 level of probability. The variables age, education, experience in farming, land holding, annual income showed positive and significant relation at 0.05 level of probability with awareness. The variable risk preference showed positive and non-significant relation with awareness possessed by the respondents. Regarding adoption, the variables i.e. age, training received, land holding, extension contact was found to be positively and highly significantly at 0.01 level of probability. The variable like education, experience in farming, annual income, possession of livestock, innovativeness showed positive and significant relation at 0.05 level of probability. Whereas the variable risk preference was found to be negatively non-significant relationship with adoption of organic farming practices. The majority of vegetable growers faced constraints in adoption of organic farming practices were non availability of organic material, low rates for organic vegetable, high labour wages, lack of timely finance, lack of subsidy on organic material, fluctuation in market rates, respectively, lack of guidance from extension personnel, lack of organic vegetable storage facilities, lack of awareness about organic farming practice, no guarantee of payment received from merchant, complicated method and lack of interest, respectively.

How to cite this article : Lothe, N.B., Gohad, V.V., Shelke, R.A. and Patil, S.B. (2017). Awareness and adoption of organic farming by the vegetable growers. Agric. Update, 12(4): 597-600; DOI : 10.15740/HAS/AU/12.4/597600 .
Author for correspondence :

\section{V.V.GOHAD}

Extension Education

Section, Shri Shivaji

Agriculture College, AMRAVATI (M.S.) INDIA

See end of the article for authors' affiliations 